\title{
Jean Philippe-Rameau and the Corps Sonore
}

\author{
By B. Glenn Chandler ${ }^{*}$
}

Jean-Philippe Rameau (1683-1764) is remembered today as a composer and music theorist. He contributed significantly to the harpsichord literature in his early years and gave us such grand dramatic compositions for the stage as Hippolyte et Aricie, Les Indes Galantes and Castor et Pollux in his later years. For his achievements he was granted the title Compositeur du Cabinet $\mathrm{du}$ Roi in 1745, which carried with it a handsome pension. ${ }^{1} \mathrm{He}$ was also incredibly proud of his theoretical writings as evidenced by the fact that he spent much of his life revising, explaining and defending his theory of the basse fondamentale, which established the triad as the building block of harmony, and the principle of the corps sonore, which he established as the scientific basis for music theory. As the result of his groundbreaking accomplishments in music theory he was known as the Isaac Newton of harmony. ${ }^{2}$

Rameau was a product of the Age of Enlightenment, a philosophical movement that swept across Europe beginning in the early eighteenth century and affected nearly every aspect of life. At the center of the movement was its emphasis on raison as the main source of authority and authentication. It nurtured the ideals of liberty, separation of church and state, tolerance, scientific methodology and reductionism. While there were significant scientific discoveries and developments in the period leading up to the eighteenth century that affected virtually every aspect of science, in the early eighteenth century music theory was still predicated on the principle of string division as established by Pythagoras when he defined the ratios of consonant intervals and justified the diatonic scale in the sixth century, B.C.E. Roman scholars transferred Pythagorean theory to medieval Europe where it became the foundation for western music. ${ }^{3}$ It was not until the year 1701 that French scientist Joseph Sauveur (1653-1716) described the acoustical phenomenon of overtones and codified the harmonic series scientifically, which became

\footnotetext{
* Professor of Music Theory \& Fellow to the Effie Marie Cain Regents Chair in Fine Arts, Butler School of Music, The University of Texas at Austin, USA.

1. Cuthbert Girdlestone, Jean-Philippe Rameau, His Life and Work, $2^{\text {nd }}$ ed. (New York: Dover Publications, Inc., 1969), 483.

2. Thomas Christensen, Rameau and Musical Thought in the Enlightenment (Cambridge: Cambridge University Press, 2006), 759.

3. Source Readings in Music History, Selected and annotated by Oliver Strunk (New York: WW Norton, 1950), 79-100.
} 
known as the principle of the corps sonore. ${ }^{4}$ Since he was a scientist rather than a musician, Sauveur did not build a harmonic theory on the principle of the corps sonore. That task was left to someone with the musicianship, curiosity and ingenuity to make the connection between overtones and music, and that person was none other than Jean-Philippe Rameau.

It is the purpose of this paper to examine the state of music theory prior to the advent of the corps sonore, including its Pythagorean mathematical basis and Rameau's revolutionary theory of the basse fondamentale as presented in his Traité de l'harmonie, ${ }^{5}$ the circumstances surrounding Rameau's discovery of Sauveur's research in acoustical science, and why he was unaware of it prior to writing the Traité; the difficulties encountered in applying the principle of the corps sonore to his previously established theory of harmony; and Rameau's methodology in the Age of Enlightenment as related to the Encyclopédistes and the extent to which he would go in defense of his principle of the corps sonore.

\section{Rameau and Music Theory Prior to the Corps Sonore}

Rameau moved to Paris in 1722 from Auvergne, where he had served as organist at Clermont-Ferrand Cathedral since 1715 and where he had penned the Traité de l'harmonie. The publication of this work soon after his arrival was much like a meteorite streaking across the Parisian sky announcing his arrival, quickly gaining him much notoriety. ${ }^{6}$ The Traité was revolutionary because it laid out his theory of the basse fondamentale as the progenitor of the triad and the triad was the building block of music. Yet as revolutionary as his theory of the fundamental bass was, the Traité was still predicated on string division and mathematical ratios in the Pythagorean tradition. Rameau was not yet aware of the acoustical discoveries of Sauveur and the principle of the corps sonore.

Rameau had been interested in theoretical studies since his youth, as he indicated later in life. While traveling in Italy at age eighteen he observed a man in the pit of the Milan Opera House one evening singing loudly the fundamental bass tones of an air. He later learned that the man was a workman with little education who had not had opportunities to hear music until recently following some good fortune, yet he was innately able to sing

4. Ian Johnson, Measured Tones: The Interplay of Physics and Music (Boca Raton: CRC Press, 2009), 90-91.

5. Jean-Philippe Rameau, Traité de l'harmonie réduite à ses principes naturels (Treatise on harmony reduced to its natural principles) (Paris: JBC Ballard, 1722).

6. Girdlestone, Jean-Philippe Rameau, 3-4. 
the foundation notes of this air. ${ }^{7}$ Thus, the principle of the fundamental bass was planted in Rameau's mind and would eventually develop, along with his desire to see music theory serve musical practice, into his Traité de l'harmonie.

There are two primary aspects of Rameau's theory of the fundamental bass, the first being chord generation and the other chord progression. He observed that the first three distinct pitches derived through harmonic division of the string following the order of Zarlino's scenario [1:2:3:4:5:6] are the three pitches of the major triad [1:3:5] and that they remain the same triad regardless of chord position or inversion and, therefore, the fundamental bass tone is the progenitor of the triad. ${ }^{8}$ Secondly, since the fifth is the first distinct interval generated through string division, he reasoned that progression by a descending fifth (or ascending fourth) is the most natural progression. A progression by descending fourth (or an ascending fifth) was also acceptable for Rameau because the fourth is the inversion of a fifth. Thus, Rameau saw in these two root progressions the only possible progressions within a modulation, or tonality. Root movement by thirds (or sixths by inversion) was also sanctioned since the third is the next interval generated through string division; however, for Rameau progression by thirds was permissible only for movement between modulations. He acknowledged that root movement by seconds and sevenths occur, but only by license-such as in the case of a deceptive cadence and a few other circumstances. ${ }^{9}$ Therefore, Rameau's theory of the fundamental bass was the unique principle upon which he based his theory of music in the Traité.

\section{Rameau and the Principle of the Corps Sonore}

Four years after the publication of the Traité Rameau published a second treatise entitled Nouveau système de musique théorique, ${ }^{10}$ which he labeled as an introduction to the Traité. In this work Rameau was clearly excited to announce the fact that nature has validated his theory of the fundamental bass

7. Jean-Philippe Rameau, "Réflexions de Monsieur Rameau sur la manière de former la voix et d'apprendre la musique" ("Reflections of Mr. Rameau on how to train the voice and how to learn music"), Mercure de France October (1752).

8. Rameau, Traité de l'harmonie, 49.

9. Ibid., 50-51.

10. Jean-Philippe Rameau, Nouveau système de musique théorique, Où l'on découvre le Principe de toutes les Regles necessaries à la Pratique: pour servir d'introduction au Traité de l'harmonie (New system of music theory, in which is discovered the principle of all the Rules Required for Practice: an introduction to the Treatise on Harmony) (Paris: JBC Ballard, 1726). 
through science since the corps sonore actually produces the three tones of the major triad, precisely the same three tones described in his theory of the fundamental bass as derived by string division. Since the publication of the Traité Rameau had learned of Sauveur's discovery through acoustical science that all sounding bodies produce the three pitches of the major triad as overtones. In the Age of Enlightenment, in which the watchword was raison and the essence of authenticity was nature, the discovery of the principle of the corps sonore was of major significance for Rameau. His delight can be heard in the preface to the Nouveau système:

There is actually in us a germ of harmony which apparently until now has not been perceived, nevertheless, is easily perceived in a string, a pipe, etc., in which the resonance produces three different sounds at once. ${ }^{11}$

This application of acoustical science by Rameau to his previously established theory of the fundamental bass then represents the beginning of a fundamental shift in music theory from a dependence on numbers to a foundation in acoustical science. The basic tenets of his theory of the fundamental bass did not change with the advent of the corps sonore; as a matter of fact, these tenets remained constant throughout his life. Some details of certain aspects of his theory did change, however, due to their incompatibility with acoustical science. Rameau would spend the remainder of his life working out aspects of these details. The Nouveau système then represents the first step in a lifetime of revision and evolution on the part of Rameau in his efforts to codify music theory on a scientific foundation.

While Rameau cited Sauveur in the Nouveau système, he did not explain how he became aware of his research and writings. ${ }^{12}$ Hans Pischner suggests it was Jean-Jeaques d'Ortous de Mairan (1678-1771) who acquainted him with Sauveur's work in 1724 when the two men met to discuss Mairan's hypothesis of air particles. ${ }^{13}$ It was also suggested that Rameau might have learned of his works from a report by Fontenelle on Sauveur's system entitled Sur un nouveau système de musique, and that Rameau might have taken the title of his new treatise from Fontenelle's work. ${ }^{14}$ And yet another possibility for Rameau's awareness of Sauveur's discoveries was through his amateurmusician student Bertrand Castel.

Jesuit priest, mathematician, journalist, and physicist, Père Louis-Bertrand Castel (1688-1757), finding Rameau's Traité fascinating, sought out the author

11. Ibid., iii.

12. Ibid., 17.

13. Hans Pischner, Die Harmonielehre Jean-Philippe Rameau (Leipzig: Breitkoph \& Härtel, 1963), 88.

14. Christensen, Rameau and Musical Thought, 138. 
through a mutual friend and soon began studying theory with him. A prolific writer, Castel then authored the rather long and glowing review of the Traité published a few months later in the Journal de Trévoux, which proved to be particularly significant in gaining Rameau notoriety throughout Europe..$^{15}$ In his review Castel made mention of the fact that M. Sauveur had already witnessed in nature what M. Rameau discovered in numbers, and that this ... was precisely the agreement of ratios and ear that Rameau was stressing in the Traité. ${ }^{16}$ It must have been bitter-sweet news for Rameau to learn of the principle of the corps sonore: sweet because the corps sonore was nature's way of validating his theory of the fundamental bass; bitter because he, the selfproclaimed expert in the field, had been unaware of this relationship and had learned of it from his amateur-musician student Père Castel.

Interestingly, it was also Castel who six years later wrote the review of the Nouveau système, but unlike the review of the Traité, which had appeared only a few months after the publication of the Traité, the review of the Nouveau système did not appear until March 1728, almost two years after its publication-quite an unusually long delay for such a review. ${ }^{17}$ This time Castel's tone was dramatically different in that his unlimited praise of the Traité had been replaced by substantive criticism. While it is not known why the review was delayed so long, or why Castel's attitude and tone changed so drastically, there are two possible explanations: (1) that Rameau was seeking someone else to write this review, perhaps a professional musician, and (2) that Castel felt slighted by the fact that Rameau did not credit him for drawing his attention to the writings of Sauveur and, therefore, was not anxious to write a second review.

In the early 1730's Rameau, evidently feeling he had exhausted his efforts to speculate on music theory, or perhaps wishing to concentrate his efforts on his newfound career in opera composition, offered to give Castel all his theoretical papers. Castel refused to accept them, however, claiming his views had diverged from Rameau's, after which they seem to have parted ways. Then in 1735 Castel published an article in the Journal de Trévoux implying that Rameau had not sufficiently acknowledged his debt to certain earlier scholars. ${ }^{18}$ A public polemic followed in a series of letters to the editor that, while basically polite, revealed an obviously strained relationship. A few

15. Graham Sadler, The Rameau Compendium (Woodbridge, Suffolk: Boydell Press, 2014), 54.

16. Louis Bernard Castel, "Traité de l'harmonie par M. Rameau," Mémories de l'Academie Royales des Sciences October-November (1722): 1713-1743, 1876-1910 (Mémories also known as Journal de Trévoux).

17. ___ "Nouveau système de musique théorique par M. Rameau," Journal de Trévoux March (1728).

18. Sadler, Rameau Compendium, 54. 
years later, when Castel wrote a not-so-flattering review of Rameau's next treatise, Génération harmonique, ${ }^{19}$ Rameau responded with such sarcasm that the Journal de Trévoux refused to print it, although it was later printed in Le Pour et contre..$^{20}$ Voltaire even showed interest in this war of words, writing a friend and suggesting he might be amused by the controversy ... that Orpheus Rameau is having with Euclid Castel. Orpheus is said to have beaten Euclid. In point of fact, I consider our musician quite strong in his own field. ${ }^{21}$

This argument between Rameau and Castel seems not to be an isolated event. According to Rameau scholar Erwin Jacobi, Rameau had a similar falling out with his pupil Therese Deshayes, who also wrote a review of Génération harmonique in 1737.22 Hughes Maret, eulogist at Rameau's funeral many years later, reported an incident in Rameau's younger days that seems to confirm his predilection for personality conflict. Rameau, having signed a twenty-nine year contract as organist at Clermont, requested to be released after seven years in order to move to Paris, citing his intent to publish his Traité as rationale for his release. When the church fathers denied his request, he determined to make them as unhappy as they had made him by denying his request. At the next service he selected the most abrasive organ stops and proceeded to play intentional discords very loudly, continuing to do so after being asked repeatedly to stop. The fathers rebuked him for his actions, after which Rameau refused to play any more until they agreed to release him from his contract. Eventually they agreed to release him, after which he played more beautifully than ever until it was time for his departure. ${ }^{23}$ His difficult personality was to affect his relations with others throughout his life.

As to the question of how Rameau became acquainted with the principle of the corps sonore, considering that Castel's review of the Traité was published in 1722 while Rameau's meeting with Mairan was not until 1724, that Castel implied in an article that Rameau had not properly acknowledged his debt to other scholars, and that Rameau had a history of abusing those close to him, it is most likely that Castel was the one who acquainted Rameau with Sauveur's research and the principle of the corps sonore.

19. Jean-Philippe Rameau, Génération harmonique, ou Traité de musique théorique et pratique (Harmonic Generation, or Treatise on Music Theory and Practice) (Paris: Prault Fils, 1737).

20. The complete texts of the Letters to the Editor found in the Journal de Trévoux and Le Pour et contre are reprinted in facsimile in: Complete Theoretical Writings of Rameau, edited with Introduction by Erwin R. Jacobi, 6 Vols. (Rome: American Institute of Musicology, 1966-72) Vol. VI.

21. Ibid., Vol. III, xvii.

22. Ibid.

23. Girdlestone, Jean-Philippe Rameau, 6-7. 


\section{Why Was Rameau not Aware of the Principle of the Corps Sonore Earlier?}

Looking back over the century prior to the publication of the Traité, much had been learned in the science of acoustics, and much of the research had taken place in Paris. The work of Marin Mersenne (1588-1648) is nothing short of spectacular considering the lack of equipment at his disposal and the stubborn metaphysical tradition still in control of most avenues of scientific endeavor in the seventeenth century. His discovery of the presence of overtones in a single tone was accomplished by his ear alone and is phenomenal despite his own rejection of its scientific explanation. ${ }^{24}$ Although Rameau cited Mersenne in the Traité, it is apparent that he did not comprehend the significance of Mersenne early research regarding the phenomenon of overtones..$^{25}$

Several others were active in this area of scientific research between the time of Mersenne and Rameau. For instance Claude Perrault (1614-1688), working in Paris, concluded that sound is provoked by atmospheric stimulation. ${ }^{26}$ John Wallis (1616-1703) appears to have been the first to explain the phenomenon of nodes in a letter published in London in 1677.27 Francis Robartes (ca. 1650-1718) attempted to unite phenomena from resonance, flageolet tones, and the trumpet series, from which he correctly identified the succession of tones in the harmonic series. ${ }^{28}$ However, it was Joseph Sauveur who, cognizant of the need for new terminology and further investigation in the new field of acoustics, convinced the Academy to set up a new section in its Mémoires under the heading of acoustics. Sauveur claimed that all resonant bodies obey the law of harmonics. He realized that the odd-numbered harmonics were easier to hear than the even-numbered ones, that the ear tends to recognize the intervals of a fifth and a third in addition to the fundamental, and that the harmonic series contains the notes of the major

24. Marin Mersenne, Harmonie universelle, contenant la théorie et la practique de la musique (Universal Harmony, containing the theory and practice of music), 2 Vols. (Paris, 1636), Facsimile ed. 3 Vols. (Paris: Editions du centre National de la Recherches Scientifique, 1963), Book IV, On instrumens, Proposition XI.

25. Rameau, Traité de l'harmonie, 9, 18, 20.

26. Claude and Pierre Perrault, Oeuvres diverses de physique et de méchanique (Various works on physics and mechanics), Vol. II; Du bruit (Leyden: Pierre Vander, 1721), 163-189.

27. John Wallis, "Dr. Wallis' Letter to the Publisher," Philosophical Transactions of the Royal Society of London XII (1677).

28. Francis Robartes, "A Discourse Concerning the Musical Notes of the Trumpet, and the Trumpet-Marine, and of the Defects of the Same," Philosophical Transactions of the Royal Society of London XVI (1692). 
chord in its two possible inversions in addition to its root position. ${ }^{29}$ Once aware of Sauveur's discoveries, it was only a short step to Rameau's application of the principle of the corps sonore to his theory of the fundamental bass.

Considering the extensive acoustical discoveries of the previous century it would not be illogical to ask why Rameau had been unaware of Sauveur's research before he wrote the Traité. One logical consideration might be his background. Being born the seventh of eleven children to an organist in Dijon might feasibly have placed him at a disadvantage in terms of cultural and intellectual opportunities as a child. In fact, it is reported that although he knew his notes before he could read, he was not a good student and that his parents were asked to remove him from school due to his disruptions and deplorable performance. ${ }^{30}$ This apparent lack of formal education would then explain why the Traité was poorly organized and difficult to comprehend. Philip Gossett, who translated the Traité into English in the mid-twentieth century, had this to say about Rameau's writing:

The prose is awkward and difficult while the vocabulary is small and mostly technical. Sentences are poorly constructed, and it is not unusual to find seven or eight independent ideas strung together with conjunctions. ${ }^{31}$

Although it appears that Rameau attempted to improve his writing in the Nouveau système by organizing his thoughts in a more logical fashion, it still consists of a very limited vocabulary and remains rough and unpolished with many misspelled words.

The circumstances of Rameau's birth and education certainly had its drawbacks and might have had an impact on his personality traits; however, in spite of his humble upbringing and lack of formal education, the fact remains that no other musician made the connection between the overtone series and music theory before Rameau, not even those living and working in Paris. Consequently, it is more likely that Rameau's unawareness of Sauveur's acoustical discoveries is attributable to the fact that: (1) virtually all musicians of the time were solidly steeped in the Pythagorean-Zarlinists tradition; (2) prior to the 1700's the field of acoustical studies pertained primarily to the process of hearing and not to the study of sound; and (3) scientific research in

29. Joseph Sauveur, "Système général des intervalles des sons, et son application à tous les systèmes et à tous les instrumens de musique" ("General System of pitch intervals, and its application to all systems and all musical instruments"), Mémories de l'Academie Royales des Sciences 1701; $2^{\text {nd }}$ ed., (1743).

30. Girdlestone, Jean-Philippe Rameau, 2-7.

31. Treatise on Harmony by Jean-Philippe Rameau, translated with an Introduction and notes by Philip Gossett (New York: Dover Publications, Inc., 1971), xxii-xxiii. 
this field was conducted by scientists and not musicians; thus, the results were less likely to be on the horizons of musicians. ${ }^{32}$

\section{Problems in Applying the Corps Sonore to his Theory of Music}

As elated as Rameau was to learn that nature validates his theory of the fundamental bass through the principle of the corps sonore, it was to prove problematic for many other aspects of his theory. For instance, in the Traité Rameau had derived all the notes of the major diatonic system from chords built on the two fundamental tones $\mathrm{C}$ and $\mathrm{F}$ except for the sixth scale degree A. This he took from his chord-of-the-added-sixth, which he built on the fourth scale degree, F-A-C-D, the source of which he interpreted as a seventh-chord built on the second scale degree D. ${ }^{33}$ After adopting the principle of the corps sonore in the Nouveau système his goal was to associate the pitches of the scale with the principle of the corps sonore, which he indicated was feasible through the geometric relationships that exist between the fundamental and its third and fifth harmonics [1:3:5]. Not only would such a relationship add unity to his theory, it would also give it a natural basis. For him both progressions [1:3] and [1:5] were important because of their numerical relationships with the germ of harmony as found in a single sound of all sonorous bodies.

In the Nouveau systeme he designated the same tones of the scale as fundamental tones, C, F and G, just as he did in the Traité, but here he referred to them as tonic and its two dominants-one above and one below. He coined the term sou-dominante for the one below tonic, which was called the chord-ofthe-sixth in the Traité. He then reasoned that since each of these fundamental tones in turn contains the germ of harmony [1:3:5], then it is from the triads of these three fundamental tones that the notes of the major scale are established. ${ }^{34}$ In order to demonstrate the harmonic relationship of the two dominants around the tonic, he assigned the number 3 to tonic rather than the number 1 as he had done before in the Traité, and then assigned the number 9 to the dominant above tonic and the 1 to the dominant below, or subdominant, resulting in the ratios [1:3:9]. From the triads formed on the subdominant $C$, tonic $G$, and dominant $D$, he deduced the major scale $[G, A$, B, C, D, E, F\#, G]. ${ }^{35}$

The problem with this arrangement, however, is that tonic is based on the number 3 and is no longer the progenitor of the other fundamental tones. In

32. Berdette L. Green, The Harmonic Series from Mersenne to Rameau (unpublished PhD dissertation, Ohio State University, 1969), 405.

33. Rameau, Traité de l'harmonie, 144.

34. Rameau, Nouveau système, iv.

35. Ibid., 38. 
this case the subdominant has become the progenitor of both the tonic and the dominant. This arrangement is contrary to the principle of unity in regards to the principle of the corps sonore in which the fundamental is the source of all the other pitches. Furthermore, it is a significant derivation from the Cartesian premise of unity as a fundamental principle. The fact that the subdominant chord is not generated by the tonic would haunt Rameau for the remainder of his life.

Equally problematic with the coming of the corps sonore was his justification of the minor mode. In the Traité he expressed the interval of a minor third mathematically in the Zarlinist tradition, through which a harmonic division of the fifth yields a major third as primary, while an arithmetic division of the fifth yields a minor third as primary. However, since the overtone series only generates a major triad Rameau began to rationalize. Admitting that although we only hear the major third in a vibrating string, he claimed that ... the minor third subsists, nevertheless, in a new comparison, which must be made between this major third and the fifth. ${ }^{36}$ In other words, Rameau claimed that the minor third exists in the vibrating string as the result of the difference between the major third from the fifth, and for Rameau that was sufficient to consider it a primary consonance. It was by the same reasoning that he justified fourths and sixths as secondary consonances. When a system of harmony is so tightly interwoven as Rameau's, a problem in one area is sure to entangle itself in related areas.

In his Génération harmonique of 1737 he sought to synthesize and present the conclusions of his reasoning from the first two treatises and to emphasize the point that music is both a science and an art and, as such, requires both theoretical speculation and practical methodology. ${ }^{37}$ Much of this treatise is taken up with his continuing efforts to bring the subdominant chord and the minor third more securely in line with his principle of the corps sonore, and in doing so he introduced two new concepts: the double emploi and reciprocal action. If a subdominant chord [C-E-G-A] progresses to a dominant chord [D$\mathrm{F} \#-\mathrm{A}-\mathrm{C}]$, then through the principle of the double emploi the [C-E-G-A] chord would be reinterpreted as an [A-C-E-G] chord in first inversion. This reinterpretation would allow the chord to progress by root relations of a fifth rather than a second, and thus adhere to his theory of chord progressions as established through the theory of the fundamental bass. According to Rameau the double emploi is permissible because the dissonance pitch $\mathrm{A}$, added to the

36. Ibid., 21.

37. Deborah Hayes, Rameau's Theory of Harmonic Generation: An Annotated Translation and Commentary of Génération Harmonique by Jean-Philippe Rameau (unpublished $\mathrm{PhD}$ dissertation, Stanford University, 1968), 256-257. 
subdominant chord may be interpreted either as an added-sixth above, or as an added-third below the fundamental bass tone C. ${ }^{38}$

The theory of reciprocal action was intended to strengthen his justification of the minor third. He incorporated Jean-Jacque d'Ortous Mairan's hypothesis of air particles through which he explained that a fundamental sound sets air particles in motion and these particles in turn set other bodies into motion at the largest common factor of 1 , and at faster speeds according to the factors of its aliquot parts of $1 / 2,1 / 3,1 / 4,1 / 5$, etc., and by discarding the octave duplications the major triad is derived. ${ }^{39} \mathrm{He}$ then mistakenly asserted that the air also produces slower vibrations through the process of reciprocal action. From this he reasoned that the corps sonore also produces the minor triad since it is a mirror of the major triad below the fundamental. ${ }^{40}$ Interestingly, in his next treatise, Démonstration du principe l'harmonie of 1750, Rameau recanted regarding the theory of reciprocal action returning to an earlier explanation of the minor chord, justifying it through art rather than science. ${ }^{41}$

\section{Rameau's Methodology and the Encyclopédistes}

As most philosophers in the early years of the Age of Enlightenment, Rameau began his theoretical writings in accordance with Cartesian methodology. ${ }^{42}$ His efforts to turn the art of music into a science reflected the eighteenth-century vogue for science, reason and mathematics. Just as Descartes had done in philosophy, Rameau rejected the authority of all musicians who had gone before and sought to establish himself as the authority and end the confusion over music theory. ${ }^{43}$ He showed admiration for Descartes through numerous quotations as well as his rationalism and deductivism by which he codified his musical theories. Like Descartes he sought to establish everything on one unique principle, his theory of the fundamental bass, which was based on string division. By rejecting some

38. Rameau, Génération harmonique, 107-119.

39. Jean-Jacque d'Ortous de Mairan, "Discours sur la propagation du son dans les differens tons qui le modifient" ("Discourse on the propagation of sound in the different tonalities by which they are modified"), Mémoires de l'Académie royale des sciences (Amsterdam, 1740).

40. Rameau, Génération harmonique, 4-6, 22-24.

41. ___ Démonstration du principe de l'harmonie, servant de base a tout l'art musical théorique et pratique (Demonstration of the principle of harmony, serving as the basis of all musical art, theoretical and practical) (Paris: Durand et fils, 1750), 62-63.

42. Desmond M. Clarke, "Descartes' philosophy of science," The Cambridge Companion to Descartes. ed. J. Cottingham (Cambridge: Cambridge University Press, 1992), 258-285.

43. Rameau, Traité de l'harmonie, 105-106. 
ancients while accepting the tenets of other ancients, such as Pythagoras' mathematics and Zarlino's scenario, Rameau exemplified a neo-classic attitude, which claims that what is true and rational is eternal and universal. ${ }^{44}$ While it may seem paradoxical to adhere to Cartesianism and neo-classicism, an eighteenth-century mind could be dogmatic and monistic, or pluralistic and selective. Descartes himself had accepted string division as his unique principle in his Compendium musicae. ${ }^{45}$ Therefore, in addition to being Cartesian, Rameau was also neo-classic.

With the advent of the corps sonore in the Nouveau système Rameau began to conduct selective experiments of the Newtonian method in order to prove his theory. ${ }^{46}$ These experiments were conducted with bowed and plucked instruments applying both listening and visual observations through which he observed that harmony, in fact, exists in nature. ${ }^{47}$ Experimentation is not usually associated with Cartesianism, but rather with Newtonianism. However, Descartes himself realized that because of its concreteness, demonstrations in physics are not identical to demonstrations in abstract geometry and found it necessary to experiment in order to verify the general mathematical laws enunciated a priori. ${ }^{48}$ Experiments are necessary in Cartesian deductivism, but the very important difference between Cartesianism experimentalism and Newtonianism is that in Cartesianism the experiment does not form the starting point or the final criterion for scientific conclusion. Descartes held that the a priori development of the fundamental laws of nature serve to set definite limits on what is physically possible, a condition explicitly repudiated by Isaac Newton (1643-1727). ${ }^{49}$ The Nouveau système was an attempt by Rameau to reconcile Cartesian tenets with Sauveur's experiments with overtones. While experimentalism began with the Nouveau système it was not until his third treatise, Génération harmonique of 1737, that he felt he had sufficiently demonstrated his theories experimentally. ${ }^{50}$

44. Jules Combarieu, Histoire de la musique des origins au debut du XXe siècle (History of Music from its origins to the beginning of the twentieth century), 5 vols. (Paris: Celin, 1913-60), vol. II, 276.

45. René Descartes, Compendium of Music, translated by W. Robert (Rome: American Institute of Musicology, 1961).

46. Paul, Rameau's Musical Theories, 159.

47. Rameau, Nouveau système, 17-20.

48. Ralph Blake, "The Role of Experience in Descartes' Theory of Method," Theories of Scientific Method: The Renaissance through the Nineteenth Century. ed. E. Madden (Seattle: University of Washington Press, 1960), 83-87.

49. __ "Isaac Newton and the Hypothetico-Deductive Method," Theories of Scientific Method: the Renaissance through the Nineteenth Century, 137-139.

50. Rameau, Génération harmonique, iii. 
Rameau had dedicated his Génération harmonique to the Royal Academy of Science and was disappointed that it had not gain him admission. On the other hand, he remained hopeful for the future because Denis Diderot (17131784), one of the chief editors and contributors to the Encyclopédie, had agreed to assist him in preparation for an upcoming lecture before the Academy. In speculation as to why Diderot might offer to assist Rameau with his speech, Thomas Christiansen suggests several reasons. Certainly Diderot admired Rameau's work, and since he was preparing the first volume of the Encyclopédie perhaps gaining the alliance of such an influential public figure as Rameau could be beneficial. Being familiar with many members of the Academy and knowing that Rameau had just been turned down for membership earlier that year, he possibly saw this as an opportunity to help him gain membership. Furthermore, he probably perceived how Rameau's theory related to some philosophical ideas with which he was actively engaged at the moment and how this could be potential for furthering his own initiatives. ${ }^{51}$

Rameau's presented his Mémoires ou l'on expose les fondements du système de musique théorique et pratique before the Academy on 19 November 1749 and it was well received, thanks in large part to an enthusiastic report by d'Alembert and others. ${ }^{52}$ Buoyed by the response, Rameau decided to use the same speech as the basis for a new treatise, and after significant revision published his Démonstration du principe de l'harmonie the same year. This treatise was well written and reads much more smoothly than any of his previous works, due primarily to Diderot's assistance with the earlier speech. With the Démonstration Rameau hoped above all to confirm his principle of the corps sonore as the scientific basis for music and quiet his detractors once and for all, and he hoped finally to be accepted into the Academy.

While the Encyclopédistes had been pleased with Rameau's speech before the Academy they were offended by his use of the word démonstration in his publication. To them this term meant proof, and that was not what he presented in his speech, or what they had approved. That was just the beginning of his difficulties, however, for it was at about the midpoint of the century that many of the intellectuals fervently rejected Cartesianism, including his Encyclopédistes friends. ${ }^{53}$ Whereas, Rameau had been praised as a true philosophe before 1750 because he shared with Diderot and d'Alembert the desire to apply science and reason to the arts, after that time he was highly criticized as a false philosophe because he continued to use certain tenets of

51. Christensen, Rameau and Musical Thought, 215.

52. Sadler, The Rameau Compendium, 75.

53. Rond d'Alembert, "Discourse preliminaire," Encyclopédie ou dictionnaire raisonne des sciences, des arts et des métiers, 6 Vols. (Paris: Briasson, David, Le Breton et Durand, 1751-80), I, i-lxxxiv. 
Cartesian methodology. ${ }^{54}$ The irony of the matter, however, is that Diderot and d'Alembert were both still quite Cartesian in certain aspects of their methodology despite their avowed Lockean epistemology. They, like Rameau, insisted upon the necessity of a simple and unique principle upon which to base facts, the complete interdependence of physical events, and the necessity and simplicity of natural law. ${ }^{55}$

Diderot and d'Alembert had introduced Rameau to the philosophical theories of John Locke (1632-1704) before they split ways over methodological issues. Lockean epistemology holds that all knowledge is acquired through sensory perception. ${ }^{56}$ Rameau explored this method of reasoning and through it soon found the sensory evidence of the corps sonore so persuasive that he began to expand his views of its principle beyond music. Wondering if the corps sonore's harmonic proportions could be found in the other fine arts, he discovered the research of architect Charles Etienne Briseux (1680-1754) who had concluded that classical architecture must be laid out along simple geometric proportions. From his research he came to the conclusion that the proportions of Rameau's corps sonore appeared to be the natural phenomenon that conveys proportions most directly to the mind. ${ }^{57}$ Encouraged by Briseux's research, Rameau was convinced that his principle of the corps sonore, in fact, applies to all the fine arts. ${ }^{58}$

Concluding that he had exhausted his efforts to reconcile the corps sonore to music and the fine arts and feeling attacked from all sides, Rameau came under the influence of Nicolas Malebranche's Occasionalism, a philosophy in which God in seen in everything. ${ }^{59}$ This was most vividly illustrated in Rameau's attempt to identify his three sounds of nature with the Christian Godhead, the Trinity. ${ }^{60}$ By paralleling God as the first cause of the universe with the principle of the corps sonore as the first cause in music, Rameau had generalized mathematical reasoning to its ultimate conclusion.

54. James Doolittle, "A Would-be Philosophe: Jean-Philippe Rameau," Modern Language Association of America LXXIV June (1959): 239.

55. Armen Vartanian, Diderot and Descartes, A Study of Scientific Naturalism in the Enlightenment (Princeton: Princeton University Press, 1953).

56. Stathis Psillos and Martin Curd, The Routledge Companion to Philosophy of Science (London: Routledge, 2010), 129-138.

57. Christensen, Rameau and Musical Thought, 232.

58. Jean-Philippe Rameau, Novelle reflections de M. Rameau sur sa Démonstration du principe de harmonie (New reflections of Mr. Rameau on his Demonstration of the principle of harmony) (Paris: Durant et Pissot, 1752), 62-63.

59. Monte Cook, "The Ontological Status of Malebranchean Ideas," Journal of the History of Philosophy 36 (1998): 525-544.

60. Jean-Philippe Rameau, "Lettre de M. Rameau aux philosophes" ("Letter from Mr. Rameau to the philosophes,") Journal de Trévoux August (1762): 2041. 


\section{Final Thoughts}

Major discoveries occur when the right circumstances and genius come together at the right time. Rameau was the right person, at the right time, with the musicianship, curiosity and genius to move music theory from the realms of numerical mysticism into the world of acoustical science. His life was an interesting journey that reflects the excitement and turbulence of the Age of Enlightment and the difficulties in codifying the functionality of tonal music. In the Traité he revealed his theory of the fundamental bass as the undergirding law of chord generation and chord progression, and he established the triad as the basic building block of music. In the Nouveau système he connected his theory of the fundamental bass to the scientific principle of the corps sonore, through which he attempted to reconcile Cartesian tenets of harmony with Sauveur's Newtonian experimentalism with overtones. In his Génération harmonique he felt he had sufficiently demonstrated his theories experimentally, although he continued to grapple with numerous aspects of his theory of music. Subsequent publications continued in his attempts to resolve conflicts and to expand the significance of the principle of the corps sonore into the fine arts and into other areas. However, by this time Rameau had moved music theory from the realms of numerical mysticism into the world of acoustical science, and in doing so had established the foundation of music pedagogy still in use today.

Although there are many inconsistences in Rameau's writings, it is important to realize that he was working in uncharted territory with insufficient vocabulary to describe functionality in music at the time. Rameau was not afraid to venture away from tradition when he found good reason to do so. He had a propensity for thinking aloud, and he was not afraid to change his mind when research and logic revealed a better way. Yet through it all he never lost sight of three essential goals: (1) music theory should serve music practice; (2) the fundamental bass as his unique principle; and (3) the principle of the corps sonore as the scientific basis for music theory.

On the occasion of the two-hundredth anniversary of his death, French musicologist, teacher and composer Jacque Chailley had this to say regarding the significance of Rameau's work:

In 2,500 years of written history, music has perhaps known only two true theoreticians... of whom the others have scarcely done anything except add to or take away from the propositions of these two. One in the sixth century B.C.E. was the incredible Pythagoras. The other .... was Jean-Philippe Rameau. ${ }^{61}$

61. Jacque Chailley, "Rameau et la théorie musicals" ("Rameau and music theory"), La revue musicale, numéro special 260 (1964): 92-93. 


\section{Bibliography}

Blake, Ralph. "The Role of Experience in Descartes' Theory of Method." Theories of Scientific Method: The Renaissance through the Nineteenth Century. ed. E. Madden. Seattle: University of Washington Press, 1960.

__. "Isaac Newton and the Hypothetico-Deductive Method." Theories of Scientific Method: the Renaissance through the Nineteenth Century.

Castel Louis, Bernard. "Traité de l'harmonie par M. Rameau." Mémories de l'Academie Royales des Sciences October-November (1722): 1713-1743, 18761910 (Mémories also known as Journal de Trévoux).

"Nouveau système de musique théorique par M. Rameau." Journal de Trévoux March (1728): 472-481.

Chailley, Jacque. "Rameau et la théorie musicals" ("Rameau and music theory.") La revue musicale numéro special 260 (1964): 92-93.

Christensen, Thomas. Rameau and Musical Thought in the Enlightenment. Cambridge: Cambridge University Press, 2006.

Clarke, Desmond M. "Descartes' philosophy of science." The Cambridge Companion to Descartes. ed. J. Cottingham. Cambridge: Cambridge University Press, 1992.

Cook, Monte. "The Ontological Status of Malebranchean Ideas." Journal of the History of Philosophy 36 (1998): 525-544.

Complete Theoretical Writings of Rameau. Edited with Introduction by Erwin R. Jacobi, 6 Vols. Rome: American Institute of Musicology, 1966-72. Vol. VI, 69-125.

Combarieu, Jules. Histoire de la musique des origins au debut du XXe siècle (History of Music from its origins to the beginning of the twentieth century). 5 vols. Paris: Celin, 1913-1960.

d'Alembert, Rond. "Discourse preliminaire." Encyclopédie ou dictionnaire raisonne des sciences, des arts et des métiers. 6 Vols. Paris: Briasson, David, Le Breton et Durand, 1751-1780.

Descartes, René. Compendium of Music. Translated by W. Robert. Rome: American Institute of Musicology, 1961.

de Mairan, Jean-Jacque d'Ortous. "Discours sur la propagation du son dans les differens tons qui le modifient" ("Discourse on the propagation of sound in the different tonalities by which they are modified"). Mémoires de l'Académie royale des sciences (Amsterdam, 1740): 1-87.

Doolittle, James. "A Would-be Philosophe: Jean-Philippe Rameau." Modern Language Association of America LXXIV June (1959): 239.

Girdlestone, Cuthbert. Jean-Philippe Rameau, His Life and Work, $2^{\text {nd }}$ ed. New York: Dover Publications, Inc., 1969.

Green, Berdette L. The Harmonic Series from Mersenne to Rameau. Unpublished PhD dissertation, Ohio State University, 1969. 
Hayes, Deborah. Rameau's Theory of Harmonic Generation: An Annotated Translation and Commentary of Génération Harmonique by Jean-Philippe Rameau. Unpublished PhD dissertation, Stanford University, 1968.

Johnson, Ian. Measured Tones: The Interplay of Physics and Music. Boca Raton: CRC Press, 2009.

Mersenne, Marin. Harmonie universelle, contenant la théorie et la practique de la musique (Universal Harmony, containing the theory and practice of music), 2 Vols. (Paris, 1636), Facsimile ed. 3 Vols. (Paris: Editions du centre National de la Recherches Scientifique, 1963), Book IV, On instrumens, Proposition XI, 210.

Perrault, Claude and Pierre. Oeuvres diverses de physique et de méchanique (Various works on physics and mechanics). Vol. II; Du bruit. Leyden: Pierre Vander, 1721.

Pischner, Hans. Die Harmonielehre Jean-Philippe Rameau. Leipzig: Breitkoph \& Härtel, 1963.

Psillos, Stathis, and Martin Curd. The Routledge Companion to Philosophy of Science. London: Routledge, 2010.

Robartes, Francis. "A Discourse Concerning the Musical Notes of the Trumpet, and the Trumpet-Marine, and of the Defects of the Same." Philosophical Transactions of the Royal Society of London XVI (1692): 559-563.

Rameau, Jean-Philippe. Novelle reflections de M. Rameau sur sa Démonstration du principe de harmonie (New reflections of Mr. Rameau on his Demonstration of the principle of harmony). Paris: Durant et Pissot, 1752.

- Traité de l'harmonie réduite à ses principes naturels (Treatise on harmony reduced to its natural principles). Paris: JBC Ballard, 1722.

_. "Réflexions de Monsieur Rameau sur la manière de former la voix et d'apprendre la musique" ("Reflections of Mr. Rameau on how to train the voice and how to learn music"). Mercure de France October (1752): 87-100.

. Démonstration du principe de l'harmonie, servant de base a tout l'art musical théorique et pratique (Demonstration of the principle of harmony, serving as the basis of all musical art, theoretical and practical). Paris: Durand et fils, 1750. . Nouveau système de musique théorique, Où l'on découvre le Principe de toutes les Regles necessaries à la Pratique: pour servir d'introduction au Traité de l'harmonie (New system of music theory, in which is discovered the principle of all the Rules Required for Practice: an introduction to the Treatise on Harmony). Paris: JBC Ballard, 1726.

. Génération harmonique, ou Traité de musique théorique et pratique (Harmonic Generation, or Treatise on Music Theory and Practice). Paris: Prault Fils, 1737. . "Lettre de M. Rameau aux philosophes" ("Letter from Mr. Rameau to the philosophes"). Journal de Trévoux August (1762): 2041.

Sadler, Graham. The Rameau Compendium. Woodbridge, Suffolk: Boydell Press, 2014. 
Sauveur, Joseph. "Système général des intervalles des sons, et son application à tous les systèmes et à tous les instrumens de musique" ("General System of pitch intervals, and its application to all systems and all musical instruments"). Mémories de l'Academie Royales des Sciences 1701; 2nd ed. (1743): 299-366.

Source Readings in Music History. Selected and annotated by Oliver Strunk. New York: WW Norton, 1950.

Treatise on Harmony by Jean-Philippe Rameau. Translated with an Introduction and Notes by Philip Gossett. New York: Dover Publications, Inc., 1971.

Vartanian, Armen. Diderot and Descartes, A Study of Scientific Naturalism in the Enlightenment. Princeton: Princeton University Press, 1953.

Wallis, John. "Dr. Wallis' Letter to the Publisher." Philosophical Transactions of the Royal Society of London XII (1677): 839-842. 